Psychology of Language and Communication 2019, Vol. 23, No. 1

\title{
Sciendo
}

DOI: $10.2478 /$ plc-2019-0002

\author{
ANNA MILANOWICZ \\ University of Warsaw, Warsaw, Poland
}

\section{A SHORT ETUDE ON IRONY IN STORYTELLING}

\begin{abstract}
This paper presents an overview of chosen concepts of irony as a communicative unit in the repertoire of the speaker. It adopts a framework of narration with emphasis on how minds in interactions co-construct meanings. Irony, which means more than it says, is always used with a specific attitude attached. Irony is thus an act of narrating the speakers' mind, but in the speaker-hearer meaning perspective.

Due to the fact that there is no narration without a text and no irony without narration, this paper links the Theory of Narrative Line and Narrative Field (Bokus, 1991, 1996, 1998) with a few selected views on the theory of irony (e.g., Clark and Gerrig, 1984; Sperber and Wilson, 1981, 1984) and research results. It also explains how the Cooperation Principle (Grice, 1975) is flouted and again recreated in the process of sharing meanings. Further, we refer to linguistic bias (Maass et al., 1989) and highlight perspective shifting in narration, which can change along the 'narrative line' and within the 'narrative field.'

This paper builds a platform for combining the theories of irony with fields of narration. This perspective situates irony as a vehicle hinged in dialectics between the explicit and the implicit, the like and the dislike, the truth and the falsehood, the praise and the criticism. All of these can be read from irony.
\end{abstract}

Key words: irony, narrative line, narrative field, storytelling, interaction, linguistic bias

\section{The stories we tell}

We are enveloped in stories. They make us who we are. Narratives engage human experience because the telling of and listening to a story activates both emotions and cognition. A string of words can affect a person in a profound way, and therefore the act of communication can be considered powerful. All communication is primarily a form of expression. The exchange of words gives rise to concrete and abstract ideas, which in turn give rise to the intuitive and

Address for correspondence: Anna Milanowicz, University of Warsaw, Stawki 5/7, 00-183 Warsaw, Poland. E-mail: ania.milanowicz@gmail.com 
conceptual worlds that we live in. We construct and share thousands of thoughts and meanings every day. We define ourselves by narratives, and by narratives we try to make sense out of things. Different voices speak different minds and tell different stories. A narrative is a closed and structured verbal representation of a sequence of events that happen over time (Labov, 1972). However, everyday stories are not merely fixed sequences of events, as they are exposed to constant changes in response to an audience. Meaningful representations of stories are not only co-constructed by the audience but also modified by the teller to fit the audience (Norrick, 2007; Milanowicz and Bokus, 2013). This participatory aspect in the co-construction of meanings allows for individual expression on the pathways of human connection, navigated by shared understanding.

"Conversation is a natural home of narrative, and the most familiar context of storytelling for most of us." (Norrick, 2007:127). Storytelling is "a social action unfolding in real time" (Blum-Kulka, 1991:101) and the product of different interactions constituting different forms of sharing (Bülow, 2004). Every story starts with a particular intention. The linguistic exchange of intentions creates a common field of attention sharing (conversation or discourse), which is an open area for multilateral communication. Norrick (2007) draws a distinction between story and narrative in that narratives do not carry any evaluation from the narrator, as opposed to a story, which always entails personal evaluation by the teller and has contextual relevance. Irony is an instance of a 'duophonic' or double-voiced narration, built on literal and interpretive levels, expressing the speaker's attitude on a particular occasion and in a particular context.

Storytelling is based on narrative competence, which is the ability to link individual pieces of representations of reality into a consistent story. This develops between 2 and 10 years of age, engaging semantics and pragmatics on three dimensions: content, plot and casual structures. The period between 2 and 5 years of age involves increased content expansion. From then on, children gradually acquire the ability to explain events in terms of internal motives and external causes, mastering the complexities of casual structures (Kemper, 1984; Bokus, 1996).

The ability to provide the addressee with adequate background information is of interest for the study of narrative development, because it requires command of both "narrative knowledge" and "storytelling performance," (Berman, 1995; Reilly, 1992) as well as the capacity to take into account the audience's needs and shared knowledge (Berman and Slobin, 1994; Menig-Peterson and McCabe, 1978), (Berman and Katzenberger, 2004:59).

The themes incorporated into one's stories are influenced by personal experiences and subjective representations. A story is the inter-mind phenomenon built not only upon the action and episodes presented by the story-teller but also interpreted by the story characters, who disclose their attitudes. These are 
respectively termed 'landscape of action' and 'landscape of consciousness' in Bokus (1991). Different narrations come from different minds who can think similarly or differently about any given situation (Bokus, 2004). This is exactly what happens in the case of irony, when different minds may differ in the representations of 'what is said' and 'what is meant.' When the narrator tells a story, different characters have different minds and therefore different representation of actions. Irony requires senders and recipients to be engaged in the interplay of minds and dialogues. Narrators (ironic text makers) and recipients (irony hearers) both make choices about the representation of the events they hear and the meaning they assign to it.

This verbal representation of the events is labelled a 'narrative line' by Bokus (1991) and placed within a 'narrative field', a background that "reflects the state of reality at a given moment within a given spatial area to which the narrator is attending" (Bokus, 1991: 197). As a matter of fact, "the narrative line' and 'the narrative field' between what the narrator says and what the hearer receives is a continuum of meanings. A text, story, narration or ironic comment is not merely an isolated unit of language but an open process of negotiations of meaning.

Producing narratives involves complex linguistic, cognitive, and social abilities (Milanowicz and Bokus, 2013). The information must be lexically encoded and decoded, its aim must be inferred from the form, context and content, and an evaluation must be assigned to its significance on the dimension of goodness and badness, pleasure and displeasure. Finally, telling a story to entertain, to criticize, to ridicule, to inform or to educate is an interactive sequence of actions and meanings that develops over time between the narrator and the hearer.

\section{The meanings we leave unspoken}

Irony entirely relies on implicatures (Attardo, 1998). The concept encounters definitional problems and its boundaries are somewhat blurred. Pragmatically, irony can be seen as a flout of Grice's (1975) Cooperative Principle (CP), though trespassed with the intention to have the hearer arrive at the implicature. Obviously, it would be a simplification to merely state that irony is a figure of speech that implies the contradiction of what is literally expressed (e.g., "you're a genius" meaning "you're stupid"), as in many cases irony goes beyond "meaning the opposite." Irony is a game of pretence (Clark and Gerrig, 1984), with actors stepping in and stepping out of their setup roles. The use of irony gives a choice of either acknowledging 'what is meant but not voiced' or referring to 'what is said but not really meant.' Brown and Levinson (1987) define irony in terms of 'understatement', not only violating Grice's Maxim of Quality (i.e. do not say what you believe to be false or not supported by evidence) but also the Maxim of Quantity (i.e. giving more or less information than needed when 
the statement "He's all right" can act either as an understated criticism implicating "He's awful" or an understated compliment meaning "He's great!"). Irony also blatantly violates the Maxim of Manner, which among others, states that one should avoid ambiguity in order to achieve efficient communication (Alba Juez, 1995). Ironically, though, the very idea of irony depends on the Cooperation between the speaker and hearer. The hearer of an ironic comment is always invited to search for the relevance of a possible interpretation. Or, as Sperber and Wilson insist: "the relevance of the ironic utterance lies in the information it gives about the speaker's attitude towards the 'attributed thought' (Alba Juez, 1995:27)

The origins of irony are traced back to ancient Greece, where the rhetorical device of 'eirōneía', meaning 'pretended ignorance', "evolved to also be applied to a deceptive use of language: to blame by ironical praise or to praise by ironical blame (Muecke, 1970)" (Li, 2008:3). Kreuz and Roberts (1993) made a distinction of four types of irony: Socratic irony of pretended ignorance, mainly for educational reasons, Dramatic irony of the character oblivious to what the audience already knows, Verbal irony of the discrepancy between the said and the meant, and finally Situational Irony of the unexpected twist of events.

According to Muecke (1970:50), the distinction between verbal irony and situational irony is reflected in the very words used to label it, namely "he or she is being ironical", while "it is ironic that..." In other words, verbal irony is being actively made, while situational irony can only be observed, hence transmits the element of passivity and helplessness in the face of the unexpected twist of fate.

From being a violation of code, a figure of speech that does not mean what it says, flouting the maxim of quality (Grice, 1975), through the game of pretense (Clark and Gerrig, 1984), to the sound of an echo (Sperber and Wilson, 1981, 1984; Kumon-Nakamura et al., 1995), and indirect negation (Giora, 1995), irony still means more than its literal words (Milanowicz, Tarnowski and Bokus, 2017).

Attitude and emotional aspect are central to irony (Attardo 2000, Shelley, 2001, Milanowicz, 2013). In the academic literature, irony oscillates on the scales of positive -negative conceptual structure. The notion of the asymmetry of the 'ironic mode' should not be, however, confused with 'ironic effects', which is the way irony is received by the hearer. While Grice $(1978,1989)$, Kerbrat-Orecchioni (1976, 1980), Sperber and Wilson (1981), and Garmendia (2010), among others, claim that irony is always negative in terms of its implicatures, Glucksberg (1995) and Brown (1980) also report some instances of irony expressing a positive attitude in a negative mode. Positive irony, involving saying something negative that one does not believe, is obviously 
considered as being more dangerous than saying something positive that one does not believe, and hence is less frequent (Myers Roy 1977; Haverkate 1990; Attardo 1998).

Ironic criticism and ironic complements are often distinguished as two basic types of verbal irony (Kreuz and Link, 2002). The two types are structurally similar to each other as both involve mock evaluations of circumstances with a valence opposite to the speaker's true appraisal. As the characteristic difference between the two, ironic praise is characterized by a negative valence in what is said and a positive valence in the appraisal that is ironically implied, while in ironic criticism the converse is true. Ironic praise can be seen as the less prevalent and less "prototypically ironic" type of irony (Kreuz and Link, 2002), (Bruntsch and Ruch, 2017:4).

Irony, more than literal language, carries the risk of miscommunication (Colston and Lee, 2004). The hearer may miss the speaker's ironic intentions and come to believe that they express something that they actually hardly intended to say. One of the benefits of the implicitness of irony is the socalled 'muting effect, i.e. the criticism communicated by implicatures does not appear as threatening and harsh as a direct criticism (Dews, Kaplan and Winner, 1995). Irony is also described as one of the manifestation of corrective humor in speech (Bruntsch and Ruch, 2017), as a shame concealing tool (Winner et al., 1998) or a face-saving technique (Leech, 1983; Brown and Levinson, 1987). However, irony can also be simply scathing, express negative emotions (Roberts and Kreutz, 1994; Gibbs 2000) or failed expectations (Sperber and Wilson, 1981; Colston and Keller, 1998).

Irony is often confused with humor. The two concepts can be overlapping but are not the same. However, the perception that humor is one of the basic functions of irony seems to be quite common and generally accepted. While "the sense of humor can be defined as relatively stable inter-individual differences in the tendency to react to humor and to produce humor, and a serene attitude toward life; see Ruch, 1998" (Bruntsch and Ruch, 2017), the sense of irony is rather a state than a disposition. The moderating effect of state (but not trait) anxiety on verbal reactions to ironic comments described by Milanowicz et al. (2017) supports this notion.

In one sense to use irony is to 'play it safe'; one does not say something directly if one does not want to put oneself at risk of offence, negative judgment, miscommunication or rapport breakage. On the other hand, by being ironic one can be at risk of misinformation. Delegating partial responsibility for 'what is meant' to the recipient constitutes a non-confrontational move. The hearer is left at the crossroads of meanings and must decide on what he or she actually hears. 


\section{The untruths we tell}

Irony and lies are cognitively more demanding than truth-telling (Dynel and Meibauer, 2016; Vrij 2006). Research shows that children enter into the lying stage at around the age of 4 (Wimmer and Perner, 1983), which co-occurs with the development of the theory of mind: the awareness that others have their own feelings and beliefs (Baron-Cohen, 1985; Astington, 2003). These two important developmental processes share the aspect of intentionality. Also, the ability to distinguish lies from jokes is correlated with the ability to correctly attribute second-order beliefs (Winner et al., 1998).

A classic definition of a lie (from Latin: mendacium) explains it as locutio contra mentem - "speaking against one's mind", a verbal expression intentionally diverse from proper beliefs (Wolniewicz, 2012). At first glance this definition might also work with the concept of irony, which is an intentional expression of something that is not true. The difference lies in the intentionality: lies are meant to deceive, but ironic comments are meant to indicate the truth.

In both cases, the speaker has the intention to communicate the deceptive meaning as if it is true. While in telling the lie, the speaker intends the hearer to accept the false information (Dynel, 2016:184), in the case of irony the speaker intends the hearer to reject it.

Therefore, it can be proposed that ironic deception is located in a moralpragmatic framework based on the harm-benefit counterbalance (I do not want to hurt one's feelings) and personal safety (I want to be liked and I do not want to lose face).

\section{The linguistic biases we live by}

The perception of words and intentions is subjective and state dependent, shaped by individual experience of each of the narration participants (Psathas, 1968). Pragmatic knowledge of narrative discourse can be considered in terms of who (narrator) is speaking to whom (listener), about what (topic), and for what purpose (Bokus and Shugar, 1998).

Irony use pertains to social norms and roles. Ironic comment can be seen as a way to apprise the recipient of social norms when transgressions occureither by playful humor or by offensive ridicule (Norrick, 1994; Bruntsch and Ruch, 2017). Listeners believe that speakers differ in their tendencies to use verbal irony, and that these differences are conveyed by certain social categories, such as occupation and gender (e.g., Katz and Pexman, 1997; Katz, Piasecka, and Toplak, 2001; Pexman \& Olineck, 2002). As shown by Katz and Pexman (2009), the speaker's job status can influence the interpretation of a figurative statement. Professionals such as comedians or a cab drivers are thought to use more irony than a doctor or a lawyer. 
A linguistic bias (LIB) is defined as a systematic asymmetry in word choice as a function of the social category to which the target belongs. LIB refers to the assumption that the desirable behavior of an ingroup member and undesirable behavior of an outgroup member are described at a relatively high level of language abstraction (e.g., the ingroup member is friendly, the outgroup member is dangerous). When the categories are reversed, that is, when an outgroup member performs desirable actions and an ingroup member acts in an undesirable way, more specific language is used (e.g., the ingroup member hits somebody, the outgroup member opens the door for someone; Maass et al., 1989). Given that expected behavior is considered to be more stable and typical than unexpected behavior, it is described better with abstract terms. Wigboldus et al. (2005) demonstrated that stereotypic expectancies give rise to differences in language abstraction, and termed this phenomenon the Linguistic Expectancy Bias (LEB). In other words, to describe behavior that is inconsistent with the male stereotype (e.g., crying), relatively more concrete language is used (e.g., he has tears in his eyes). In contrast, when describing a crying woman-stereotype consistent behavior - relatively more abstract language is used (e.g., she is fragile). Following this line of thinking, if the desirable behavior of an ingroup member is interpreted on a more abstract level than negative behavior, and the process is reversed for outgroup members (Wigboldus and Douglas, 2007), it can be expected that irony, as the manifestation of a more complex and abstract mental action, should be used differently by ingroup (e.g., same-sex, same occupation, same race) than outgroup members (e.g., opposite-sex, different professional category, different cultural or racial background). Milanowicz, Tarnowski and Bokus (2017) observed the effect of gender in the use of irony. Not only did men use more irony than women, which reconfirms previous studies (Colston and Lee, 2005; Ivanko, Pexman, and Olineck, 2004, Kreuz and Link, 2004), it was also shown that in the case of a negative irony (criticism) women used more irony to a man (out-group members) than to a woman. This tendency was reversed for positive irony (i.e. ironic compliment), where men and women would rather reply ironically to a comment made by a woman.

This switch in the patterns of use of ironic comments indicates that both irony and storytelling are sensitive to sociocultural factors.

Linguistic biases reflecting gender effects were also previously described in 9-10 year olds. Research showed that children start to accommodate their narrations to their audience at the age of approximately 9-10 years, proposing different solutions to ingroup (same sex) than outgroup (oppositesex) members and shifting their perception of moral problems accordingly (Milanowicz and Bokus, 2013).

The stories we produce and the interpretations of narrations that we make depend on the context of social comparisons. Almost any variable stimulus 
can act as a point of reference, e.g.: sex, nationality, age or education, etc. We are benchmarking our verbal performance against those criteria of "sameness" and "otherness." Both, children and adults adjust their communication to accommodate the social context (Milanowicz and Bokus, 2013; Milanowicz et al., 2017). "Confirming a shift from personal to social identity, women described themselves as more relational in the intergroup context than in the intragroup context ... In contrast, men described themselves as less relational in the intergroup context compared to the intragroup condition ..." (Guimond et al. 2006: 230).

Narrations are "jointly constructed" by the teller and the audience (Cuff and Hustler, 1981; Kemper, 1984; Norrick 2007; Bülow, 2004). The storyteller automatically monitors the expectations and reaction of the audience, responding to the setting and the outcome.

\section{Conclusions: the answers that we look for}

So far most studies on irony have focused on its detection and comprehension (Colston and Gibbs, 2007). Less attention was given to the production of ironic utterances (Averbeck and Hample, 2008; Hancock, 2004; Rockwell and Theriot, 2001; Kotthoff , 2003; Milanowcz et al., 2017). Likewise, there are studies investigating the speaker's perceived intent in "ironic insults" (Kreuz and Link, 2002) and "ironic compliments" (Pexman and Olineck, 2002). Detection of ironic criticism and detection of ironic praise can be found as two inter-correlated but discriminant facets of irony detection aptitude (Bruntsch and Ruch, 2017).

Numerous comparative studies have investigated the processing times (i.e., response latencies) of ironic and literal stimuli (Schwoebel, Dews, Winner, and Srinivas, 2000), producing inconsistent results of either one-stage (Gibbs 1986, 1994; Sperber and Wilson 1986 ) or two-stage processing mechanisms (Grice 1975, 1989; Giora, 1997). Researchers have also analysed the neural mechanisms (Spotorno et al., 2012) and use of contextual cues (facial expression, tone of voice, situation setting) in irony comprehension (Anolli, Ciceri, and Infantino, 2002; Todorov, Said, Engell, and Oosterhof , 2008, Akimoto and Miyazawa, 2017 ). Irony in narration is used almost every day by different language users in various contexts. There are always more studies on social aspects in irony processing (Gibbs, 2000) Mewhort-Buist and Nielsen, 2012; Ivanko, Pexman, and Olineck, 2004), though the questions of personality and culture remain largely unaddressed. For example, according to BBC (http://news.bbc.co.uk/1/hi/magazine/3433375. $\mathrm{stm})$, in the UK there is a persistent notion that Americans don't get irony: "Los Angeles-based British actor Tim Curry didn't pause for a second when asked what he missed most about the UK. 'Irony' he replied." 
As in narration, irony is not merely an isolated unit of a message, but an open process of negotiating meanings by making sense of 'what is said' and' what is meant.' The negotiations are set between 'what we want to say', 'what we think we say',' what we actually say', and 'what is really heard and understood' by the other person. These are very distinct units of meaning making.

Irony comprehension - just like story comprehension - rests on the acts of interpretation, co-construction and selections of episodes from the potential continuum of meanings. What we say does not only describe but also creates the reality, and the words we use can bring about unintended consequences. Words can act as filters and regulatory mechanisms. The choice of what we say, when, and to whom is not only dictated by one's preferences but also the perceptions of others and their expectations. The stories we tell develop over time and change within changing landscapes of consciousness.

\section{References}

Alba Juez, L. (1995). Verbal Irony and the Maxims of Grice's Cooperative Principle. Revista Alicantina de Estudios Ingleses, 8, 25-30.

Akimoto, Y., \& Miyazawa, S. (2017). Individual Differences in Irony Use Depend on Context. Journal of Language and Social Psychology, 36(6), 675-693.

Anolli, L., Ciceri, R., \& Infantino, M. G. (2002). From" blame by praise" to" praise by blame": Analysis of vocal patt erns in ironic communication. International Journal of Psychology, 37(5), 266-276.

Astington, J. W. (2003). Sometimes necessary, never sufficient: False-belief understanding and social competence. In B. Repacholi \& V. Slaughter (Eds.), Individual differences in theory of mind: Implications for typical and atypical development (pp. 13-38). New York, NY: Psychology Press.

Attardo, S. (1998). Irony as relevant inappropriateness. Journal of Pragmatics, $32,793-826$.

Baron-Cohen S, Leslie A. M., \& Frith, U. (October 1985). Does the autistic child have a "theory of mind"?. Cognition, 21(1), 37-46.

Berman, R. A. \& Katzenberger, I. 2004. Form and function in introducing narrative and expository texts: A developmental perspective. Discourse Processes, 38(1), 57-94.

Berman, R. A. (1995). Narrative competence and storytelling performance: How children tell stories in different contexts. Journal of narrative and life history, 5(4), $285-313$.

Blum-Kulka, S. (1997) Dinner talk: Cultural patterns of sociability and socialization in family discourse. Mahwah, NJ: Erlbaum.

Bokus, B. (2004). Inter-mind phenomena in child narrative discourse. Pragmatics, 14(4), 391-408. 
Bokus, B. (2000). Światy fabuly w narracji dziecięcej (Story worlds in child narration). Warszawa: Energeia.

Bokus, B. (1998). Pole narracji: pejzaż akcji i pejzaż świadomości w opowiadaniach dziecięcych (The narrative field: landscape of action and landscape of cosciousness in children's stories). In: M. Smoczyńska (Ed.), Studia z psychologii rozwojowej i psycholingwistyki (Studies in the developmnetal psychology and psycholinguistics) (pp. 211-217). Kraków: Universitas.

Bokus, B. \& Shugar, G. W. (1998). Social structures of children's narrational activity. Psychology of Language and Communication, 2(1), 75-81.

Bokus, B. (1996). Narrative space structuring at the preschool age. Findings on monologic and dialogic discourse. In: C. E. Johnson \& J. H. V. Gilbert (Eds.), Children's language (vol. 9, pp 197-207). Mahvah, NJ: Erlbaum.

Bokus, B. (1991). Children's pragmatic knowledge of narrative tasks. In: J. Verschueren (Ed.), Pragmatics at Issue, Part I (pp. 13-28). Amsterdam: John Benjamins.

Brown, P. \& Levinson, S. C. (1987). Politeness: Some universals in language usage. Cambridge: Cambridge University Press

Bruntsch, R. \& Ruch, W. (2017). Studying irony detection beyond ironic criticism: Let's include ironic praise. Frontiers of Psychology. doi:https:// doi.org/10.3389/fpsyg.2017.00606

Bülow, P.H. (2004). Sharing experiences of contested illness by storytelling. Discourse and Society, 15(1), 33-53.

Clark, H., \& Gerrig, R. (1984). On the pretense theory of irony. Journal of Experimental Psychology: Genral, 113, 121-126. doi: 10.1037/00963445.113.1.121

Colston, H. L. \& Lee, S. Y. (2004). Gender differences in verbal irony use. Metaphor and Symbol, 19(4), 289-306.

Cuff, E. C. \& Hustler, D. (1981). Adult-child conversation. London: Croom Helm.

Dews, S., Kaplan, J., \& Winner, E. (1995). Why not say it directly? The social functions of irony. Discourse Process. 19, 347-367. doi: $10.1080 / 01638539509544922$

Dynel, M. \& Meibauer, J. (2016). Everything You always wanted to know about the pragmatics of deception but were afraid to test. International Review of Pragmatics, 8(2), 163-178.

Dynel. M. (2016). Killing Two birds with one deceit. Deception in multi-party interaction. International Review of Pragmatics, 8(2), 179-218.

Garmendia, J. (2010). Irony is critical. Pragmatcs \& Cognition, 18, 397-421. doi:10.1075/pc.18.2.07gar

Garmendia, J. (2013). Ironically saying and implicating. What Is Said and What Is Not. The Semantics/Pragmatics Interface, 225-24. 
Gibbs, R. W. (2000). Irony in talk among friends. Metaphor and Symbol, 15 (1-2), 5-27.

Gibbs, R.W. (1986). On the psycholinguistics of sarcasm. Journal of Experimental Psychology: General, 115, 3-15.

Gibbs, R.W. (1994). The poetics of mind. Cambridge: Cambridge University Press.

Giora, R. (1997). Understanding figurative and literal language: The graded salience hypothesis. Cognitive Linguistics, 8(3),183-206

Giora, R. (1995). On irony and negation. Discourse Process, 19, 239-264. doi:10.1080/01638539509544916

Guimond, S., Chatard, A., Martinot, D., Crisp, R. J., \& Redersdorff, S. (2006). Social comparison, self-stereotyping, and gender differences in selfconstruals. Journal of Personality and Social Psychology, 90(2), 221-242. doi: 10.1037/0022-3514.90.2.221

Grice, H. P. (1975). Logic and conversation. In P. Cole and J. L. Morgan (Eds.), Syntax and Semantics Vol. 3: Speech Acts (pp. 41-58). New York, NY: Academic Press.

Halliday, M.A. K. (1975). Learning how to mean: Explorations in the development of language. New York, NY: Elsevier.

Haverkate, Henk, 1990. A speech act analysis of irony. Journal of Pragmatics, 14(1), 77-109.

Ivanko, S. L., Pexman, P. M., \& Olineck, K. M. (2004). How sarcastic are you? Individual differences and verbal irony. Journal of Language \& Social Psychology, 23, 244-271.

Katz, A., Piasecka, I., \& Toplak, M. (November 2001). Comprehending the sarcastic comments of males and females. Paper presented at the 42nd Annual Meeting of the Psychonomic Society, Orlando, FL.

Keenan, E. (1974). Conversational competence in children. Journal of Child Language, 1, 163-183.

Keltner, D., Capps, L., Kring, A. M., Young, R. C., \& Heerey, E. A. (2001). Just teasing: a conceptual analysis and empirical review. Psychological Bulletin, 127, 229-248. doi: 10.1037/0033-2909.127.2.229

Kemper, S. (1984). The development of narrative skills: Explanations and entertainments. In Discourse development (pp. 99-124). Springer, New York, NY.

Kotthoff, H. (2003). Responding to irony in diff erent contexts: On cognition in conversation. Journal of Pragmatics, 35(9), 1387-1411.

Kreuz, R.J. \& Link, K.E. (2002). Asymmetries in the Use of Verbal Irony. Journal of Language and Social Psychology, 21(2):127-143.

Kreuz, R.J. \&R. Roberts. 1993. On satire and parody: The importance of being ironic. Metaphor and Symbolic Activity (8), 97-109. 
Kumon-Nakamura, S., Glucksberg, S., \& Brown, M. (1995). How about another piece of pie: the allusional pretense theory of discourse irony. Journal Experimental Psycholgy: General, 124, 3-21. doi:10.1037/00963445.124.1.3

Labov, W. (1972). Language in the Inner City: Studies in the Black English Vernacular. Philadelphia, PA: University of Pennsylvania Press.

Leech, G. N. (1983). Principles of Pragmatics. New York, NY: Longman

Li, X. (2008). A Cross-Cultural Exploration of Situational Irony in China and the United States. Sino-Platonic Papers, 184.

Maass, A., Salvi, D., Acuri, L., \& Semin, G. R. (1989). Language use in intergroup contexts: the linguistic intergroup bias. Jouranl of Personality and Social Psychology, 57, 981-993. doi: 10.1037/0022-3514.57.6.981

Milanowicz, A., Tarnowski, A., \& Bokus, B. (2017). When sugar-coated words taste dry: The relationship between gender, anxiety, and response to irony. Fronters of Psycholgy. https://doi.org/10.3389/fpsyg.2017.02215

Milanowicz, A., \& Bokus, B. (2013). Gender and moral judgments: the role of who is speaking to whom. Journal of Gender Studies, 22, 423-443. doi: 10.1080/09589236.2012.719314

Muecke, D. (1970). Irony. Norfolk, Fakenham: Methuen \& Co Ltd.

Myers Roy, A. (1977). Towards a definition of irony. In: R. W. Fasold \& R. Shuy (Eds.), Studies in language variation (pp. 171-183). Washington, DC: Georgetown University Press.

Norrick, N. R. (1994). Involvement and joking in conversation. Journal of Pragmatics, 22, 409-430. doi: 10.1016/0378-2166(94)90117-1

Norrick, N. R. (2007). Conversational storytelling. In: D.Herman (Ed.), The Cambridge Companion to Narrative (pp. 127-141). Cambridge Univeristy Press.

Pexman, P. M. \& Olineck, K. M. (2002). Does sarcasm always sting? Investigating the impact of ironic insults and ironic compliments. Discourse Processes, 33, 199-217.

Psathas, G. (1968). Comment. American Psychologist, 23, 135-137

Sperber, D., \& Wilson, D. (1981). Irony and the use-mention distinction. In P. Cole (Ed.), Radical Pragmatics (pp. 295-318) New York, NY: Academic Press.

Sperber, D., \& Wilson, D. (1984). Pragmatics: an overview. In S. Georges (Ed.), From the Lingusistics to the Social Context (pp. 21-41). Bologna: Cooperativa Libraria Universitaria Editrice.

Schwoebel, J., Dews, S., Winner, E., \& Srinivas, K. (2000). Obligatory processing of the literal meaning of ironic utterances: further evidence. Metaphor Symbol, 15, 47-61. doi:10.1080/10926488.2000.9678864

Spotorno, N., Koun E., Prado J., Van Der Henst J.B.,\& Noveck I.A.(2012). Neural evidence that utterance-processing entails mentalizing: the case of irony. Neuroimage, 63(1), 25-39. doi:10.1016/j.neuroimage.2012.06.046. 
Todorov, A., Said, C. P., Engell, A. D., \& Oosterhof, N. N. (2008). Understanding evaluation of faces on social dimensions. Trends in Cognitive Sciences, 12(12), 455-460.

Weir, R. (1960). Language in the crib. The Hague: Mouton.

Wigboldus, D. H. J., \& Douglas, K. (2007). Language, stereotypes, and intergroup relations. In K. Fiedler (Ed.), Social communication (pp. 79-106). New York, NY: Psychology Press.

Wigboldus, D. H. J., Spears, R., \& Semin, G. R. (2005). When do we communicate stereotypes? Influence of the social context on the linguistic expectancy bias. Group Processes \& Intergroup Relations, 8(3), 215-230. doi:10.1177/1368430205053939

Wimmer, H. \& Perner, J. (1983). Beliefs about beliefs: representation and constraining function of wrong beliefs in young children's understanding of deception. Cognition, 13, 103-128.

Winner, E., Brownell, H., Happé, F., Blum, A., \& Pincus, D. (1998). Distinguishing lies from 5 jokes: Theory of mind deficits and discourse interpretation in right hemisphere brain- 6 damaged patients. Brain and Language, 62, 89-106. doi:10.1006/brln.1997.1889

Wolniewicz, B. (2012). O pojęciu Kłamstwa i Zasadzie Prawdomówności. Edukacja Filozoficzna, 54, 1-23.

Vrij, A. (2006). Detecting Lies and Deceit. Pitfalls and Opportunities. 2nd ed. Chichester: John Wiley. 